(C) 2007 Bioethics 21(5): 283-289.

\title{
A THOMISTIC PERSPECTIVE ON THE BEGINNING OF PERSONHOOD: REDUX
}

\author{
Jason T. Eberl
}

\section{Introduction}

I wish to thank Jan Deckers for his careful critique of my article. ${ }^{1}$ As it happens, I largely agree with Deckers's overall assessment of my previous argument. Further research since the publication of that article has led me to conclude that the account I previously defended is not sufficiently compelling to negate the conclusion that, from a Thomistic metaphysical perspective, a human embryo is rationally ensouled at conception. I have developed my current view in two publications to which I refer the reader. $^{2}$ In this response, I will indicate the points on which Deckers and I agree or disagree, and conclude by discussing a particular theological issue Deckers raises.

\section{Why Deckers Is Right}

Deckers asserts that "the fact that early embryos depend on the right environment for their survival cannot be used to support the claim that they are not ensouled." 3 This assertion, I now contend, is correct. An embryo's requirement of a supportive, nutritive uterine environment does not preclude its possessing an active potentiality to develop itself into an actually thinking rational being. A uterus provides a supportive environment for an embryo to exercise its own developmental capacity. Uterine implantation does not

\footnotetext{
${ }^{1}$ See J. Deckers. Why Eberl Is Wrong: Reflections on the Beginning of Personhood. Bioethics 2007; 21: [\#]; J.T. Eberl. The Beginning of Personhood: A Thomistic Biological Analysis. Bioethics 2000; 14: 13457.

2 J.T. Eberl. Aquinas's Account of Human Embryogenesis and Recent Interpretations. Journal of Medicine and Philosophy 2005; 30: 379-94; J.T. Eberl. 2006. Thomistic Principles and Bioethics. New York.

Routledge: ch. 2.

${ }^{3}$ Deckers, op. cit. note 1, p. [\#].
} 
alter an embryo's intrinsic nature or bestow upon it more inherent potentialities than it already possesses.

The form of external assistance a uterus provides is akin to an astronaut's spacesuit or an underwater explorer's submarine. Each provides what the person needs to exercise her vital metabolic capacities; but the lack of such support does not entail that she lacks those capacities. If an astronaut's spacesuit malfunctions and stops supplying oxygen, her vital metabolic functions will cease shortly thereafter. If, however, a fellow astronaut fixes her suit in a timely fashion and restores the flow of oxygen, her vital metabolic functions will resume. This indicates that the astronaut's intrinsic capacity for such functions remained despite the loss of the requisite supportive environment. ${ }^{4}$ Another relevant example is the incubator most prematurely born infants require to continue their post-natal development. Although such infants cannot survive without the incubator's assistance, their dependence on it does not entail that their potentiality for full development is merely passive and not self-directed. ${ }^{5}$

Deckers also correctly notes that there is evidence of an inchoate organization and intercommunication among the cells that constitute an early embryo. ${ }^{6}$ Such organization and intercommunication may also indicate functional interdependence among the cells. Evidence of an inchoate organization among an early embryo's cells is their coming together at implantation to form the primitive streak, as well as other embryonic and extra-embryonic tissues shortly thereafter. Germain Grisez thus charges that "[Norman]

\footnotetext{
${ }^{4}$ Does the astronaut's dependence on her fellow astronaut's assistance in restoring her supportive environment imply that her potentiality for being alive is merely passive? No, because the assistance provided does nothing to alter or replace the astronaut's organic structure by which she is able to breathe in and circulate oxygen once it is made available to her again.

${ }^{5}$ These examples are taken from Eberl, op. cit. note 2 (2006), p. 85.

${ }^{6}$ See Deckers, op. cit. note 1, p. [\#]. This paragraph and the following are taken from Eberl, op.cit. note 2 (2006), pp. 35-6.
} 
Ford $^{7}$ has trouble explaining why a few thousand distinct individuals work together in embryogenesis to make themselves into one individual. ${ }^{, 8}$ Other critics of Ford's account have noted that an embryo has an "identifiable body plan" before implantation and formation of the primitive streak. ${ }^{9}$

Furthermore, as Deckers notes, Ford acknowledges that there is some sort of "clock" mechanism programmed in a zygote's DNA that guides organic development and "continues through childhood for the growth of teeth, biological changes at puberty, adulthood etc. right through to old age." ${ }^{\prime 10}$ This clock "seems to be set from the time of fertilization, with each cell's 'clock' running in dependence on, and in co-ordination with, what is happening in its surrounding cells. ${ }^{, 11}$ Ford interprets this phenomenon as supporting his view that each cell constituting an early embryo is a distinct individual organism that has its own internal clock, which is synchronized with the clocks of the other cells. Grisez counters that such harmonious synchronization to be what one would expect if such cells "are, not a mass of distinct individuals, but integral parts of one developing individual." 12

\footnotetext{
${ }^{7}$ See N. Ford. 1988. When Did I Begin? Conception of the Human Individual in History, Philosophy and Science. New York. Cambridge University Press. My previous argument is largely indebted to Ford's account in this work.

${ }^{8}$ G. Grisez. When Do People Begin? Proceedings of the American Catholic Philosophical Association 1989; 63: 27-47. Cf. P. Lee. 1996. Abortion and Unborn Human Life. Washington, D.C. Catholic University of America Press, 102; C. Tollefsen. Embryos, Individuals, and Persons: An Argument Against Embryo Creation and Research. Journal of Applied Philosophy 2001; 18: 72; R. George. Human Cloning and Embryo Research. Theoretical Medicine and Bioethics 2004; 25: 14-15.

${ }^{9}$ See J. Vial Correa and M. Dabike. 1998. The Embryo as an Organism. In Identity and Statute of Human Embryo. J. Vial Correa and E. Sgreccia, eds. Vatican City. Libreria Editrice Vaticana: 317-28; A. Serra and R. Colombo. 1998. Identity and Status of the Human Embryo: The Contribution of Biology. In Vial Correa and Sgreccia, op. cit. note 9; A. Fisher. When Did I Begin? Revisited. Linacre Quarterly 1991; 58: 66; P. Flaman. When Did I Begin? Another Critical Response to Norman Ford. Linacre Quarterly 1991; 58: 46.

${ }^{10}$ Ford, op. cit. note 7, p. 155 , n. 37.

${ }^{11}$ Ford, op. cit. note 7, p. 155.

${ }^{12}$ Grisez, op. cit. note 8, p. 38. Cf. Tollefsen, op. cit. note 8, p. 72.
} 
Finally, Deckers rightly argues that the apparently random nature of cellular differentiation - which parts of the body or extra-embryonic organs each cell will ultimately form - also does not preclude an early embryo's internal organization: "the fact that these cells differentiate at all, and in particular ways, suggests the existence of a determining factor or organising principle that is internal to the embryo."13 Benedict

Ashley goes further to describe the differentiation that occurs as early as the zygote's first cleavage:

From the moment of fertilization there already exists in the zygote (and this was probably already pre-determined in the ovum) a metabolic polarity, with the nucleus determining the upper pole of the metabolic gradient, and a bilaterality which will eventually be fundamental to the plan of the adult body. Consequently, as the first cell-divisions take place, there is already some differentiation in the cytoplasm of the daughter cells. They may be totipotential when separated, but as existing in the morula, they already constitute heterogeneous parts. ${ }^{14}$

Various studies on the development of mouse embryos support Ashley's description of an inherent organizational structure in a zygote and its daughter cells that determines an early embryo's future biological development. ${ }^{15}$

\footnotetext{
${ }^{13}$ Deckers, op. cit. note 1, p. [\#].

${ }^{14}$ B. Ashley. 1976. A Critique of the Theory of Delayed Hominization. In An Ethical Evaluation of Fetal Experimentation: An Interdisciplinary Study. D. McCarthy and A. Moraczewski, eds. St. Louis. Pope John XXIII Center, 123. Cf. B. Ashley and A. Moraczewski. Cloning, Aquinas, and the Embryonic Person. The National Catholic Bioethics Quarterly 2001; 1: 197; George, op. cit. note 8, p. 14.

${ }^{15}$ See R.L. Gardner. The Early Blastocyst is Bilaterally Symmetrical and Its Axis of Symmetry is Aligned with the Animal-Vegetal Axis of the Zygote in the Mouse. Development 1997; 124: 289-301; R.L. Gardner. Specification of Embryonic Axes Begins Before Cleavage in Normal Mouse Development. Development 2001; 128: 839-47; R.L. Gardner. Thoughts and Observations on Patterning in Early Mammalian Development. Reproductive Biomedicine Online 2002; 4: 46-51; K. Piotrowska and M. Zernicka-Goetz. Role for Sperm in Spatial Patterning of the Early Mouse Embryo. Nature 2001; 409: 517-21; K. Piotrowska, F. Wianny, R.A. Pedersen, and M. Zernicka-Goetz. Blastomeres Arising from the First Cleavage Division have Distinguishable Fates in Normal Mouse Development. Development 2001; 128: 3739-48; R. Beddington and E. Robertson. Axis Development and Early Asymmetry in Mammals. Cell 1999; 96: 195-209.
} 


\section{The Nature of the Soul and the Metaphysics of Twinning}

Despite my overall agreement with Deckers's criticisms of my previous argument, he makes two erroneous contentions. First, he refers to Christian Munthe's claim that the thesis that a substance's divisibility precludes its being ensouled is based on "the Platonic-Cartesian idea of the soul as an indivisible substance or "ego." "16 It is not accurate, however, to characterize my previous argument as implying such a description of the rational soul that informs a person's body. According to the Aristotelian-Thomistic concept, a rational soul is indivisible insofar as it is essentially the substantial form of a particular body: "Therefore, just as it is of the soul's nature that it is the form of a body, so it is of this soul's nature, insofar as it is this soul, that it has an inclination toward this body." "A rational soul can thus be described as the "blueprint" for the particular body of which it is the substantial form. ${ }^{18}$ This understanding of the relationship between a rational soul and its body stands opposed to the Platonic-Cartesian view in which it does not necessarily matter to which body a particular soul is conjoined. While both views imply the soul's indivisibility, they do so for different reasons.

The second, more significant, point of disagreement stems from Deckers's reference to the example, raised by John Haldane and Patrick Lee, ${ }^{19}$ of a flatworm's divisibility which does not preclude its being ensouled - in this case, by a sensitive

\footnotetext{
${ }^{16}$ Deckers, op. cit. note 1, p. [\#]. See C. Munthe. Divisibility and the Moral Status of Embryos. Bioethics 2001; 15: 395.

${ }^{17}$ Aquinas. Quaestio disputata de spiritualibus creaturis [QDSC]: IX ad 4. R. Spiazzi, ed. 1949. Quaestiones disputatae, vol. 2. Turin. Marietti. Cf. QDSC: IX ad 15; Aquinas. Quaestio disputata de anima [QDA]: I ad 10. All translations are my own and are taken, unless otherwise noted, from the Leonine edition of Aquinas's works: Aquinas. 1882- . S. Thomae Aquinatis Doctoris Angelici Opera Omnia. Rome. Commissio Leonina.

${ }^{18}$ See J.T. Eberl. The Metaphysics of Resurrection: Issues of Identity in Thomas Aquinas. Proceedings of the American Catholic Philosophical Association 2000; 74: 221. For a fuller treatment of a rational soul's relationship to the body it informs, see J.T. Eberl. Aquinas on the Nature of Human Beings. Review of Metaphysics 2004; 58: 333-65.

${ }^{19}$ See J. Haldane and P. Lee. Aquinas on Human Ensoulment, Abortion, and the Value of Life. Philosophy 2003; 78: 274.
} 
soul. ${ }^{20}$ This example is intriguing, because Aquinas also discusses the phenomenon of flatworm division and compares a flatworm's soul with a human person's:

It must be said that in those animals which live when divided there is one soul in act and many in potency. Now through division they are brought forth into an actual multitude, as happens in all forms which have extension in matter. ${ }^{21}$

Aquinas describes a flatworm as having one soul before it is divided. Its soul, however, is "potentially many" since, if the flatworm is properly divided, its soul will become "actually many." It thus seems that a flatworm's soul can be "divided" through division of its matter. Because of its potentiality for such division, a flatworm may exist as a unified substance and then cease to exist by being divided. The original flatworm's soul ceases to be one as its potential to be many is actualized.

Aquinas's construal of a flatworm's division does not preclude its existence as an individual substance before its division. ${ }^{22}$ Nevertheless, a flatworm does not survive the division. Neither of the two resulting flatworms is identical to the original; neither flatworm has the same soul as the original, for the original's soul ceased to exist when it was divided into many ${ }^{23}$ Hence, Aquinas's metaphysical construal of a flatworm's division does not cohere with embryonic twinning unless it is the case that a rationally ensouled embryo dies when it divides into twins who are each a newly created person. Aquinas thus distinguishes the possible division of a flatworm's soul from the impossible division of a rational soul:

\footnotetext{
${ }^{20}$ A "sensitive" soul has the relevant capacities for life and sensation, but not rationality, and is the type of soul proper to all non-human species of the animal genus. See Aristotle. De anima: II.2-3.

${ }^{21}$ QDSC: IV ad 19. Cf. Aquinas. Quaestiones disputatae de potentia Dei [QDP]: III.12 ad 5; Aquinas. Sententia super Metaphysicam [In M]: VII.16.1635; Aquinas. Sententia libri De anima [In DA]: II.4.

${ }^{22}$ See Aquinas. Scriptum super sententiis magistri Petri Lombardi [In Sent]: I.8.v.3 ad 2.

${ }^{23}$ See E. Stump. 2003. Aquinas. New York. Routledge, 41.
} 
Soul united to a body [i.e., a rational soul] is not multiplied in the way of material forms which are divisible by the division of their subject, but remains in itself simple and one. ${ }^{24}$

While Aquinas would not endorse the comparison of a flatworm's division to embryonic twinning, this comparison does not purport twinning to involve the same metaphysical implications as a flatworm's division. The main point is that the potentiality to divide into two or more organisms does not preclude an organism's previous substantial unity; this is the same for both flatworms and embryos. Nevertheless, whereas a flatworm's division involves the division of its soul, and thereby the original flatworm's destruction, an embryo's soul cannot be so divided.

This results in a sharp distinction between Deckers's conclusion regarding embryonic twinning, given rational ensoulment at conception, and my current view. I propose that, when an embryo twins, it is not the case that it is "dividing," but that it loses some of its matter - a cluster of cells. Since the separated cell cluster is totipotent, i.e., it has an active potentiality to develop into an actually thinking rational being, it is informed - once divided - by a newly created rational soul. ${ }^{25}$ It is not necessary to accept Ford's conclusion that an embryo's potentiality to divide is a threat to its previous substantial unity. Furthermore, the understanding of twinning as an event in which an embryo loses some of its matter, rather than dividing like a flatworm, allows for an embryo to maintain its substantial unity through the twinning process and result in one of the twins being identical to the original embryo. ${ }^{26}$

\footnotetext{
${ }^{24}$ QDP: V.10 ad 6. R. Spiazzi, ed. 1949. Quaestiones disputatae, vol. 2. Turin. Marietti. Cf. Aquinas. Summa contra gentiles [SCG]: II.86; QDSC: IV ad 9; QDA: X ad 15.

${ }^{25}$ Aquinas holds that each rational soul is created within the body it informs directly by God. This claim will be discussed at length in the final section.

${ }^{26}$ This conclusion is originally stated in Eberl, op. cit. note 2 (2006), p. 39. Of course, it would be most difficult to establish any epistemic criteria for determining which of the twins is the same as the original.
} 
This view is contrary to Deckers's assertion that, in cases of embryonic twinning, "Both twins were one embryo during their earliest developmental stages, and at some point started developing in separation from each other. Their 'ongoing ontological identity' is not threatened by the fact that they once were only one individual." ${ }^{, 27}$ This claim implies Rose Koch-Hershenov's contention that there are two "co-located" souls in embryos that are destined to twin. ${ }^{28}$

Koch-Hershenov's contention is problematic for several reasons. First, it goes against Aquinas's argument that only one rational soul informs the matter of each individual human organism. ${ }^{29}$ Second, Koch-Hershenov and David Hershenov argue that the metaphysical possibility of spatially coincident objects, such as a statue and the lump of clay that constitutes it, supports the possibility that a single embryo may constitute two human organisms - and thus two persons. ${ }^{30}$ This argument requires that there may be spatially coincident objects of the same kind. Hershenov defends this thesis by using the example of two roads that converge at a certain point: the same bricks and gravel constitute two different roads, one from Santa Barbara to Las Vegas and the other from Los Angeles to Las Vegas. ${ }^{31}$ Even if Hershenov’s thesis were accepted, however, it does not follow that two organisms - or two persons - may be spatially coincident.

Such epistemic uncertainty, however, does not preclude the ontological claim that one of the twins is identical with the original while the other is not.

${ }^{27}$ Deckers, op. cit. note 1, p. [\#].

${ }^{28}$ See R. Koch-Hershenov. Totipotency, Twinning, and Ensoulment at Fertilization. Journal of Medicine and Philosophy 2006; 31: 158-60.

${ }^{29}$ See In DA: II.5; Aquinas. Summa theologiae [ST]: Ia.76.3-4; Aquinas. De unitate intellectus contra Averroistas: I.

${ }^{30}$ See J. Eberl, R. Koch-Hershenov, and D. Hershenov. The Metaphysical Nuances of Hylomorphism. The National Catholic Bioethics Quarterly 2006; 6: 11.

${ }^{31}$ See D. Hershenov. Can There Be Spatially Coincident Objects of the Same Kind? Canadian Journal of Philosophy 2003; 31: 1-22. 
Furthermore, it is at odds with Aquinas's argument that two physical bodies - e.g., the

bodies of two human organisms - cannot be spatially coincident:

If two bodies are in the same place, it follows that the dimensions of both bodies are the same as the dimensions of the place. It thus follows that they are the same as each other, which is impossible.

Consequently, since matter is subject to dimensions as found in all bodies, it must be that any two bodies are prohibited, by the very nature of corporeity, from being in the same place. ${ }^{32}$

Finally, it is not in line with Aquinas's logic to hold that something's being

divisible entails that it is already metaphysically divided, even if spatially coincident, into two distinct substances: "For, because a thing is divisible, it is not thereby many except potentially"; "Yet it is not the case that in such animals [e.g., divisible flatworms] any part is called an animal before division, except potentially." ${ }^{34}$ So, if I am physically divisible, it does not entail that I am actually many distinct substances. I am potentially many, in that part of my matter may cease to compose me and come to compose another substance. ${ }^{35}$ This type of potentiality, however, is passive in that an external agent must act upon me to make the division actual; I cannot naturally divide myself. In the same way, an embryo that may divide into identical twins has only a passive potentiality for such division, ${ }^{36}$ which does not preclude its actual existence - prior to the division - as one substance: a rationally ensouled human person.

\footnotetext{
${ }^{32}$ Aquinas. Expositio super librum Boethii De trinitate: IV.3.

${ }^{33}$ In M: V.8.884. R. Cathala and R. Spiazzi, eds. 1950. Turin: Marietti.

${ }^{34}$ In Sent: I.8.v.3 ad 2. P. Mandonnet and M. Moos, eds. 1929-47. 4 volumes. Paris: Lethielleux.

${ }^{35}$ An example of such division would be if one of my somatic cells were separated from me and used to create a clone.

${ }^{36}$ While the biological process of twinning is not fully understood, it appears to be a random event, with no apparent internal genetic factor or any clear environmental factor that causes an embryo to twin. See A.

Piontelli. 2002. Twins: From Fetus to Child. New York. Routledge, 19. To the best scientific understanding, it is as likely that twinning is caused by factors respective of the uterine environment acting upon weak intercellular bonds to cause the embryo to lose some of its cells as it is that an embryo is genetically "programmed" to divide. If there were a genetic determiner for twinning intrinsic to an embryo,
} 


\section{Divine Creation of Rational Souls}

I now turn to a theological issue Deckers raises concerning whether God directly creates each rational soul. Aquinas argues that a rational soul cannot result, as in the case of other forms of material substances, simply from matter being actualized in the appropriate way:

The intellective soul ${ }^{37}$ cannot be educed from the potentiality of matter; for it was already shown above ${ }^{38}$ that the intellective soul itself entirely exceeds the power of matter, because it has an operation without matter ... Therefore, the intellective soul is not educed into being through the transmutation of matter, nor through the action of a power in semen. ${ }^{39}$

A rational soul's intellective capacities are not dependent upon any material body for their functioning insofar as such capacities surpass the limits of matter in their ability to understand the universal forms of things; such universal forms are the natures of things understood as abstracted from any particular material conditions. Since intellective capacities surpass the limits of matter, no purely material process can be responsible for the generation of substantial forms with such capacities. All other substantial forms of material substances can be generated through purely material processes. Aquinas thus argues that a rational soul must receive its existence directly from God:

It must be said that it is from the first cause [God] that such a soul has its existence, also that it is intellectual and is a soul and consequently that it is impressed in a body. ${ }^{40}$

then one could argue that this factor precludes an embryo that has it from being an individual substance prior to its division. There is, though, no conclusive evidence of an intrinsic genetic determiner for twinning. See Ford, op. cit. note 7, p. 119.

${ }^{37}$ The term "intellective soul" is synonymous with "rational soul."

${ }^{38}$ See SCG: II.68, 78; ST: Ia.75.2; In Sent: I.8.v.2 ad 1.

${ }^{39}$ SCG: II.86.

${ }^{40}$ Aquinas. In librum de causis expositio: V. C. Pera, ed. 1955. Turin. Marietti. Cf. ST: Ia.90.2, 118.2; SCG: II.87-8. See N. Kretzmann. 1999. The Metaphysics of Creation: Aquinas's Natural Theology in Summa contra gentiles II. Oxford. Clarendon Press, 384-6. 
The process of human generation, therefore, is twofold insofar as natural procreative activity yields a body that is suited to being informed by a rational soul, but the soul must be directly created in the body by God. ${ }^{41}$

Deckers argues that God should not be understood as the cause of a rational soul informing a newly formed human embryo. First, he asserts that Aquinas's account raises the problem of "how the soul might be able to function without a body." ${ }^{, 42}$ Second, in response to the general account that God causes some things - e.g., a rational soul's existence - and not others - e.g., a flatworm's sensitive soul or the form of a statue constructed through human artifice - raises the problem that "divine causation can be postulated to explain anything." ${ }^{43}$ Third is the problem of why God does not abstain from creating rational souls in embryos formed through illicit sexual activities, such as adultery or rape. Deckers concludes with a "view that God does not cause anything" and that "no divine intervention is required" for a human person to exist once sperm and ovum unite in fertilization. ${ }^{44}$

It is not evident how Aquinas's account yields Deckers's first problem, since it is a rational soul's capacity to function intellectively without its body that is the basis for his argument that it must be created directly by God. Deckers correctly cites, however, an apparent inconsistency in my previous view as I carelessly state, "All types of form are essentially integrated with the matter they inform. They cannot exist separate from matter. ${ }^{, 45}$ While this is true for all other forms of material substances - including a

\footnotetext{
${ }^{41}$ See SCG: II.89; QDP: III.9 ad 5; L. Farmer. Human is Generated by Human and Created by God. American Catholic Philosophical Quarterly 1996; 70: 413-27.

${ }^{42}$ Deckers, op. cit. note 1, p. [\#].

${ }^{43}$ Deckers, op. cit. note 1, p. [\#].

${ }^{44}$ Deckers, op. cit. note 1, p. [\#].

${ }^{45}$ Eberl, op . cit. note 1, p. 138.
} 
flatworm's soul or the form of a statue - and such forms are thereby corrupted when their bodies die or are destroyed, a rational soul is only naturally integrated with its body. A rational soul is essentially incorruptible and can function intellectively without its body; yet, even when it is separated at death, a rational soul maintains its essential nature as the "blueprint" for its particular body and will re-inform the body at the Resurrection. ${ }^{46}$

It is also not evident how Deckers's second problem is implied by Aquinas's account. If divine causation ${ }^{47}$ is allowed in the case of a rational soul, it does not follow that anything can be reasonably postulated to be caused by God. Whenever an event occurs or something comes to exist for which a purely naturalistic explanation suffices, then it is proper, per Ockham's Razor, not to postulate a divine cause. Aquinas argues, however, that a rational soul's existence cannot be sufficiently explained in purely naturalistic terms. Deckers does not critique Aquinas's argument on its own terms and merely asserts that the natural process of procreation is sufficient to account for a rational soul's existence. Deckers needs to offer a metaphysical explanation for how a purely material process can produce a form which is essentially immaterial. ${ }^{48}$

Deckers's third problem raises the classical "problem of evil." He begins by assuming that it is "inappropriate" for God to create a rational soul in cases of adultery or rape. He notes Aquinas's response that God cooperates, not with the sinful desires of those engaged in illicit intercourse, but with the good procreative event that results. ${ }^{49}$ Deckers then neglects, however, the inherent good of a new human life being created and

\footnotetext{
${ }^{46}$ See Eberl, op. cit. note 18 (2000); J.T. Eberl. Pomponazzi and Aquinas on the Intellective Soul. The Modern Schoolman 2005; 83: 65-77.

${ }^{47}$ Of the various types of causes defined by Aristotle and adopted by Aquinas, only God's role as a proximate efficient cause is at issue here. God's being the existential foundation or the ultimate final cause of everything that exists is not the focus of Deckers's critique.

${ }^{48}$ This is analogous to the contemporary debate in the philosophy of mind in which it is argued that the immaterial properties of consciousness cannot be wholly explained by the physical properties of the brain. ${ }^{49}$ See ST: Ia.118.2 ad 5.
} 
implicitly presumes that there is nothing good about a life created through adultery or rape. On the contrary, Aquinas holds that a person's existence is intrinsically good, no matter what other negative consequences may be attendant upon her existence. ${ }^{50}$

Deckers notes Aquinas's contention that fornication is sinful "because intercourse between people who are not committed to one another could damage the new life that may thus be generated." fornication brings about an inordinateness which tends toward [vergit] the injury of the life of the offspring who is born from such sexual intercourse." ${ }^{52}$ Aquinas's point is that a father who is not committed to the mother may not be available to raise his child properly. This unhappy consequence, though, is not a direct result of the procreative activity in which God participates, but of a further decision on the father's part not to be involved with his child. Nothing prevents a child created through fornication or adultery from being properly raised by both of her biological parents - or by adequate substitutes - and it is for this purpose that God participates in such illicit sexual activity by creating a rational soul if an appropriate body is naturally produced..$^{53}$

Deckers's approach to this problem is more akin to the Platonic-Cartesian understanding of the soul, in which it is completely up to God to decide when and where, and under what circumstances, a rational soul comes to exist in a particular human body. On the contrary, it is more in line with the Aristotelian-Thomistic understanding of the

\footnotetext{
${ }^{50}$ See Eberl, op. cit. note 2 (2006), p. 71.

${ }_{51}^{51}$ Deckers, op. cit. note 1, p. [\#].

${ }^{52}$ ST: IIa-IIae.154.2, emphasis mine. For an application of this claim to the issue of reproductive cloning, see Eberl, op. cit. note 2 (2006), pp. 90-2.

${ }^{53}$ Admittedly, the case of rape is more difficult to contend with. It must be kept in mind, however, that no amount of "damage" which results for the life of a child conceived through such an act would be sufficient to negate the intrinsic goodness of the child's very existence, according to Aquinas.
} 
soul to adopt the notion, as one reviewer suggested to Deckers, ${ }^{54}$ that God had ordained it as a "rule" that every appropriately formed human body would be informed by a rational soul created in it. Since Aquinas argues that a rational soul is properly united to a human body, ${ }^{55}$ and that God does not create souls without appropriate bodies to inform, ${ }^{56}$ it is most appropriate for God to cooperate with the natural order rationally ordained by God's eternal law $^{57}$ and not violate this order routinely in cases of sinful procreative activity. In conclusion, it is worth noting that this problem does not relate only to Aquinas's claim that God directly creates each rational soul. Assuming Deckers's own conclusion that a rational soul is generated through the natural procreative process without divine intervention, one can ask why, in cases of adultery or rape, God does not stop this natural process or annihilate the rational soul before the person can fully develop. In broader terms, just as Deckers may question why God created a rational soul for Adolf Hitler or Osama bin Laden knowing the negative impact each would have on the world, one may question why God did not intervene to stop the natural process by which Hitler or bin Laden were created according to Deckers. Of course, this invokes the general problem of evil which is beyond the scope of this response, but is a problem with which both Aquinas's and Deckers's views must contend.

\footnotetext{
${ }^{54}$ See Deckers, op. cit. note 1, p. [\#].

${ }^{55}$ See ST: Ia.76.5; SCG: II.90.

${ }^{56}$ See ST: Ia.118.3; SCG: II.83.

${ }^{57}$ See ST Ia-IIae.94.1, 93. God's eternal law includes not only the natural moral law, but also the physical laws of nature.
} 